\title{
A HISTÓRIA DO SABER ENQUANTO DETERMINANTE DO FILOSOFAR: UMA BREVE INTRODUÇÃO A FILOSOFIA DA HISTÓRIA DE MICHEL ONFRAY
}

\author{
Artur Rodrigo Itaqui Lopes Filho ${ }^{1}$
}

\section{Resumo:}

A filosofia enquanto processo histórico constantemente promove uma seleção de autores/escolas/sistemas, justificando tal ação de acordo com a relevância histórica e as contribuições trazidas por estes para com aquilo definido e aceito enquanto saber filosófico contemporâneo. Esse processo não somente legitima aquilo que será levado adiante para as próximas gerações enquanto saber filosófico, mas também segrega e por que não, expulsa autores/sistemas/escolas de seu conjunto, promovendo assim uma verdadeira separação entre o filosófico e o não-filosófico. Sobre qual principio regulador tal segregação é orientada? Qual o critério determinante para que este ou aquele autor/sistema/escola venha constituir parte da história da filosofia em detrimento de outros que não constituem espaço em seu estudo? Diante dessa complexa situação o filósofo contemporâneo Michel Onfray (1959) pretende acusar o desenvolvimento histórico do saber humano como processo intencional de manipulação histórica promovido pelas instituições de poder em determinados períodos da história da humanidade, a saber: a antiga academia de Platão e o catolicismo medieval. Essas instituições teriam em suas respectivas épocas o poder de instituir um critério de demarcação determinante entre o filosófico e o não-filosófico, o qual selecionaria aquilo que por sua vez passaria a ser compreendido pelas gerações seguinte como de fato um saber filosófico. Tal perspectiva remete a obra escrita por Michel Onfray: Contra História da Filosofia (2008) onde o autor apresenta dois movimentos aparentemente distintos, mas que constitui em seu processo um elo causal o qual acaba por corroborar para com sua teoria da história. O primeiro movimento se refere filosofia enquanto resultante de um conflito histórico iniciado na antiga Grécia de Platão, com fins de instituir o verdadeiro meio pelo qual nos seria possível alcançar a verdade, algo que acabaria, por consequência, promovendo o surgimento de um critério de demarcação entre o filosófico e o nãofilosófico. O segundo movimento viria como consequência da instauração de um único e verdadeiro modus filosófico: o respaldo a tradição. Tais processos acabariam por promover o surgimento de uma história da filosofia hegemônica que por sua vez viria a orientar o filosofar das futuras gerações.

Palavras-Chave: Michel Onfray, Filosofia, História, Poder, Hegemonia.

\begin{abstract}
:
Philosophy as historical process constantly promotes a selection of authors/schools/systems, justifying such action according to historical relevance and

\footnotetext{
${ }^{1}$ Bacharel em Comunicação Social (ESPM); Licenciado em Filosofia (UNILASALLE); Mestre em Filosofia (UNISINOS); Doutorando em Filosofia (PUCRS).
} 
contributions brought by these towards what is defined and accepted as contemporary philosophical knowledge. This process does not legitimates only things that will be taken by the next generations as philosophical knowledge, but it also segregates and why not, expel authors/schools/systems from its whole, promoting a true separation between the philosophic and the non-philosophic. From which controlling principle this segregation is orientated by? What is the determinant criterion to this or that author/school/system come to constitute part of the history of philosophy in detriment of others that don't construct any space in its study? Before this complex situation, the contemporary philosopher Michel Onfray (1959) intends to accuse the historical development of human knowledge as an intentional process of historical manipulation promoted by powerful institutions in determined periods of mankind's history, namely: the ancient academy of Platon and medieval Catholicism. These institutions would have had in their respective times the power to institute a determinant demarcation rule between the philosophical and the non-philosophical, which would select things that could be understood as philosophical knowledge for the next generations. This perspective refers to the work written by Michel Onfray: Counter History of Philosophy (2008) where the author presents two movements that are seemingly disparate, but they constitute in their process a causal link which turns out to corroborate with his theory of history. The first movement refers philosophy as a result of a historical conflict started in Plato's ancient Greece, in order to establish a real way which we could reach the truth, something that would end, as result, promoting the emergence of a demarcation criteria between philosophical and non-philosophical.The second movement would come as a result of the establishment of the only real philosophical modus: the support to the tradition. Such processes would ultimately promote the emergence of a history of the hegemonic philosophy which in turn would guide the philosophical thoughts of future generations.

Keywords: Michel Onfray, Philosophy, History, Power, Hegemony.

\section{Introdução}

O presente artigo tem por objetivo apresentar a perspectiva defendida pelo filósofo contemporâneo Michel Onfray (1959) acerca daquilo que este compreende por filosofia e como seu pensamento, em dadas proporções, acaba por abalar as estruturas daquilo que concebemos até então enquanto área magna do conhecimento, sua prática e sua legitimidade acadêmica.

Diretamente influenciado pela filosofia de Friedrich Nietzsche (1844-1900) $)^{2}$ o autor nascido na frança e defensor de uma prática filosófica que transcenda os limites da

\footnotetext{
${ }^{2}$ As influências para o desenvolvimento de sua tese se encontram nos escritos da juventude de Friedrich Nietzsche, em especial sua Segunda Consideração Intempestiva: da utilidade e desvantagem da história para vida (1874), O nascimento da tragédia no espírito da música (1872) e A filosofia na idade trágica dos gregos (1873).
}

\begin{tabular}{|l|l|l|l|l|} 
Revista Dialectus & Ano 1 & n. 2 & Janeiro-Junho 2013 & p. 165-179 \\
\hline
\end{tabular}


academia, estabeleceu sua posição enquanto filósofo ao questionar as bases nas quais a tradição acadêmica, até a contemporaneidade se encontra fundada. Através de uma leitura paralela da história, Onfray acabou por se deparar com inúmeras sistemas/escolas/autores alternativos que, segundo declarado por um grande conjunto de ditos historiadores da filosofia $^{3}$, não vieram a angariar uma posição de destaque devido a uma estranha não relevância do pensamento defendido e propagado pelos mesmos frente ao movimento do esclarecimento iniciado na Grécia antiga de Platão e Aristóteles. Algo que remete a uma espécie de qualidade intrínseca existente no pensamento desenvolvido por cada autor/sistema/escola do saber dito filosófico que, ao atingir certo grau de impacto/destaque, passaria a ser merecedor do mérito de compor a grande história da filosofia.

Cético diante desse modo de se conceber a história da filosofia, Onfray passou a desenvolver um grande conjunto de textos desmistificando autores cânones dos estudos filosóficos, acusando os mesmos de angariarem uma posição de destaque dentro do corpus filosófico contemporâneo, pouco devido a qualidade e aprofundamento de suas respectivas investigações, e sim, devido a uma espécie de adequação a um modus de como agir e pensar estabelecido pela tradição que o precedera. Tal modus teria sua origem não na ascensão de um saber que, teoricamente teria se mostrado mais verdadeiro que outro em meio ao grande processo de desenvolvimento histórico, pelo contrário, teria sua origem em um verdadeiro embate político que teria por objetivo a instauração de uma única verdade: o meio verdadeiro para se chegar a verdade.

Aquele que viesse a deter o meio, aqui descrito enquanto modus, capaz de desvelar a verdade acerca das grandes questões que assombram a humanidade desde os primórdios até a contemporaneidade, determinaria, de certo modo, aquilo que viria a constituir a filosofia de fato. Assim um verdadeiro confronto passaria a ser estabelecido. O prêmio? A instauração de um modus pelo qual toda a humanidade passaria a trabalhar suas idéias, coroado pelo título de pensamento filosófico de fato.

O problema encontrado por Michel Onfray frente a lógica do combate histórico, que teria por finalidade estabelecer o meio verdadeiro para se chegar a verdade se daria

\footnotetext{
${ }^{3}$ Com a finalidade de expor ao menos uma das muitas justificativas dada pelos igualmente muitos escritores da história da filosofia acerca da segregação promovida pelos mesmos, selecionamos aquela apresentada pelo Padre Leonel Franca (1893-1948) em sua obra Noções de história da filosofia (1987), que diz: "O critério único, que em semelhantes apreciações deve servir de norma ao historiador, é o critério da evidência, é a conformidade das doutrinas com os primeiros princípios da razão. Julgada aos reflexos desta luz, a verdade ressairá sempre mais brilhante e o erro, cedo ou tarde, se manifestará no absurdo de suas contradições" (FRANCA, 1987, p. 19).
}

\begin{tabular}{|l|l|l|l|l|} 
Revista Dialectus & Ano 1 & n. 2 & Janeiro-Junho 2013 & p. 165-179 \\
\hline
\end{tabular}


em seu inevitável resultado prático. Ao afirmar um único modus como o verdadeiro meio para se alcançar a verdade, outras muitas maneiras de se pensar o complexo que constitui a existência humana e sua relação com o mundo a sua volta passariam a serem condenados ao esquecimento ou a marginalidade, vide o fato destes representarem, por consequência de tal processo, os meios não-verdadeiros de se chegar a verdade. Com isso, autores/sistemas/escolas filosóficas estariam delegados a um novo critério de demarcação o qual segregaria o filosófico do não-filosófico.

Dotado de tal perspectiva, Onfray acusa a filosofia contemporânea de trair em larga escala sua proposta inicial erigida pelos gregos séculos atrás: libertar o pensamento e permitir a livre reflexão acerca do homem e do mundo a sua volta. Assim escreve o autor:

[Nesse contexto, é] filósofo o personagem que coloca sua inteligência, seu saber, sua retórica e seu trabalho a serviço do poder instalado e forja para o uso dos poderosos um arsenal conceitual que permite, em seguida, a legitimação política de sua ação (ONFRAY, 2011, p. 1).

Acusando a filosofia contemporânea de respaldar uma história constituída de autores/sistemas/escolas que remontam um modus de pensar instituído, defendido e aceito como a verdade filosófica pelas instituições de poder vigente - a saber, a academia -, em detrimento a outras muitas maneiras pouco conhecidas e abandonadas de filosofia - de certo negadas pela tradição -, Onfray passou a dedicar sua produção filosófica a ministrar cursos e escrever textos e livros reforçando cada vez mais sua acusação. Assim o autor escreve em seu artigo Misérias (e grandezas) da filosofia ${ }^{4}$ :

\begin{abstract}
No que me diz respeito, proponho [...] uma contra-história (filosófica) da filosofia, concentrando-me nos mecanismos da historiografia clássica: contra a tradição [...] - a tirania dos mecanismos platônicos, cristãos e alemães -, é proposta [...] uma leitura do arquipélago pré-cristão visto do lado anti platônico, atomista, materialista, cínico, cirenaico, epicurista; uma desconstrução da fábula cristã e o exame das diversas dimensões, bem como de seu contexto das resistências ao cristianismo - agnósticas, epicuristas renascentistas e humanistas [...]. O objetivo? Mostrar a existência, ocultada pela instituição, de uma filosofia alternativa, crítica, radical, hedonista, praticável, útil e existencial (ONFRAY, 2011, p. 7).
\end{abstract}

Assim, o presente artigo apresentará em uma primeira parte a concepção de Michel Onfray acerca da história como polemologia, tendo como objetivo expor enquanto síntese aquilo o que o autor concebe por filosofia e a importância de sua história para o seu desenvolvimento. Em uma segunda parte será buscado apresentar os exemplos erigidos pelo autor acerca do processo de desenvolvimento de um critério de

\footnotetext{
${ }^{4}$ Publicado originalmente na revista francesa: Le monde diplomatique. Traduzido para o português por Iraci Poleti. Possível de ser acessado pelo sitio: http://diplo.uol.com.br/imprima1003
}

\begin{tabular}{|l|l|l|l|l|}
\hline Revista Dialectus & Ano 1 & n. 2 & Janeiro-Junho 2013 & p. 165-179 \\
\hline
\end{tabular}


demarcação histórico existente entre o filosófico e o não-filosófico, o qual vem a corroborar para com sua teoria da história.

\section{A História como Polemologia}

Michel Onfray é um dos mais contestados crítico e igualmente criticado filósofo da contemporaneidade devido suas obras que, de maneira objetiva, pretendem acusar a existência de uma espécie de hegemonia do pensamento filosófico ocidental contemporâneo. Em meio a afirmações e refutações efusivas frente ao academicismo e toda a aura que sustentou e sustenta a filosofia no ocidente até os dias atuais, Michel Onfray rapidamente se tornou uma personalidade contestada e apontada como persona non grata dentre muitos círculos/centros de estudos, visto que em tão pouco tempo, sua produção filosófica ganhara tamanha proporção, não muito devido a qualidade de sua pesquisa, mas sim devido a ousadia assumida por este em acusar abertamente o processo do domínio do diferente como responsável pela ascensão de uma única faceta do amplo saber filosófico, isto é, segundo Onfray, a filosofia com a qual inúmeros pesquisadores trabalham na contemporaneidade, seria fruto de um processo de domínio e, igualmente, domesticação de todo pensamento considerado, de certo modo, subversivo ao ideal filosófico previamente estabelecido pela tradição que a precedera.

Sua acusação é sustentada pela crença de haver uma espécie de hegemonia filosófica ocidental resultante de um processo de domínio e submissão de todo pensamento que por sua vez viesse a transgredir a lógica de um grupo seleto de pensadores - a saber, a academia - que, ao dominar e subjugar seus contrapostos intelectuais, passariam a determinar aquilo que hoje conhecemos por filosofia.

Em resumo, o autor acusa a existência de uma ascensão de um saber filosófico que se constrói em medida que a história da humanidade vem se desenvolvendo. $\mathrm{O}$ problema se encontra na concepção de história que este assume logo nas primeiras paginas de sua obra Contra-História da Filosofia (2008). Para o filósofo francês, a história da humanidade se refere ao relato documentado/sustentado por aqueles que detém uma posição de poder em determinados períodos da grande história. Segundo Onfray a história da humanidade é a história dos vencedores que de maneira intencional deixaram registrado aquilo que por sua vez lhes convinha a ser documentado.

Essa intencionalidade historiográfica nos instiga a entender a história como o relato intencional daqueles que em certos períodos da grande história estiveram em uma

\begin{tabular}{|l|l|l|l|l|} 
Revista Dialectus & Ano 1 & n. 2 & Janeiro-Junho 2013 & p. 165-179 \\
\hline
\end{tabular}


posição de tamanho poder capaz de decidir o que seria delegado as próximas gerações enquanto memória material e intelectual.

Ao pensarmos a história dessa maneira, não nos seria difícil imaginar que a grande filosofia que aceitamos ter nascido enquanto movimento de amor ao saber na antiga Grécia de Platão e Aristóteles igualmente teria sido fruto de uma segregação do pensamento enquanto reflexo dessa mesma lógica. Ao atribuirmos tal lógica a história da filosofia e incorporarmos a mesma como um possível relato dos vencedores, passaríamos a pensar a filosofia não mais como o desenvolvimento do conhecimento humano (que não estranhamente abusa sempre dos mesmos referenciais - nos alerta o autor ${ }^{5}$ ), e sim, passaríamos a entender a filosofia como o desenvolvimento de uma faceta do conhecimento que se tornou hegemônico devido as mesmas articulações políticas que fizeram inúmeras nações ascender ao custo do sucumbir de muitas outras.

A filosofia a qual entendemos e aceitamos contemporaneamente é acusada por Onfray de ser reflexo de um processo de doutrina, segregação e execução de autores/sistemas/escolas do pensamento humano, considerados válidos ou não ao título de filosofia de fato, sendo tal título atribuído por uma comissão de ditos eruditos no assunto em respaldo a uma tradição acusada por ele de instituir uma pseudo-verdade acerca daquilo que constitui a grande filosofia, ao custo do rechaço e da desqualificação de outras muitas maneiras possíveis de se pensar/trabalhar o todo complexo que constitui o foco de estudos da filosofia desde então. Seguindo sua lógica, aqueles que detêm o poder de decidir acerca da verdade filosófica passariam a julgar e segregar o filosófico do não-filosófico, portanto instituindo-se aí uma lógica de poder pouco afável referente ao desenvolvimento da filosofia em sua completude. Cito o autor:

\begin{abstract}
De fato, um filósofo, uma doutrina, um pensamento, um sistema, um livro, uma reflexão, uma obra só existem quando inscritos num processo histórico. História da filosofia, certamente, mas também história simplesmente. Cada momento se lê - se liga - em um movimento. O ponto dado de um tempo filosófico funciona na dialética de uma longa duração. Que autor invisível conta ao público a odisseia em seus detalhes? Quem escreve a história da filosofia, em outras palavras: quem diz a verdade filosófica? (ONFRAY, 2008a, p. 12-13).
\end{abstract}

A instigante acusação do filósofo francês tem por objetivo mobilizar os leitores a uma problemática que constituiria as bases daquilo que comumente é adotado e

\footnotetext{
${ }^{5}$ Para o autor, não estranhamente abusa dos mesmos referencias devido a intencionalidade intrínseca àqueles que pretendem manter a filosofia tal e qual a mesma vem sido sustentada e justificada pela estrutura acadêmica, de tempos remotos até a contemporaneidade. Onfray assim escreve: "Como um erro ou uma distorção da realidade repetido dez vezes, cem vezes, mil vezes, torna-se verdade (ainda mais quando sua proliferação emana dos grandes, dos poderosos, dos oficiais, das instituições), esse tipo de mentira piedosa passa por certeza definitiva" (ONFRAY, 2008a, p. 15).
}

\begin{tabular}{|l|l|l|l|l|} 
Revista Dialectus & Ano 1 & n. 2 & Janeiro-Junho 2013 & p. 165-179 \\
\hline
\end{tabular}


igualmente aceito enquanto verdade filosófica. Sua crítica pretende retirar o pensador dito filósofo de sua zona de conforto o levando a refletir acerca de questões que muito raramente estes se deparam em suas respectivas reflexões. Pensar a filosofia como uma construção histórica, fruto de um jogo de poder político, obriga a todos aqueles adeptos a essa tradição a duvidar das bases nas quais sua própria instituição se encontra fundada. Assim escreve Onfray:

Nenhuma história da filosofia impõe-se como única, a não ser num país totalitário que dá sua versão oficial. No entanto, assim como os manuais escolares dirigidos por pessoas diferentes, até mesmo escrito por indivíduos dissemelhantes, publicados por editoras concorrentes, contam a mesma epopeia, mudando apenas alguns detalhes, a forma, as histórias da filosofia com frequência passam uma única e mesma narração.

Mesmos autores, mesmos textos de referência, mesmos esquecimentos, mesmas negligências, mesmas periodizações, mesmas ficções contudo apontadas mas repetidas à larga - por exemplo, a existência de um Demócrito pré-socrático, por definição anterior a Sócrates, mas que lhe sobrevive em trinta a quarenta anos!

Por que esses instrumentos ideológicos que sempre são os manuais, as ontologias, as histórias, as enciclopédias que, certamente, fazem as mesmas afirmações, silenciam sobre as mesmas informações? (ONFRAY, 2008a, p. 13).

Segundo a perspectiva defendida por Onfray a concepção de história da humanidade enquanto história dos vencedores é a chave para que venhamos a entender o grande processo de domínio do diferente enquanto ascensão e instauração daquilo que veio a ser conhecido e difundido até a contemporaneidade enquanto filosofia. Tal lógica segue uma peculiar interpretação adotada pelo autor frente ao grande movimento histórico que, conforme Onfray é possível de ser observado em determinados momentos da grande história da humanidade.

Para tanto, a determinação de uma verdade, seja ela qual for, não poderia estar fundada apenas em uma lógica simples de imposição do discurso do forte opressor sobre o fraco temerário, segundo o autor, acreditar que todo o desenvolvimento do conhecimento seria reflexo dessa simples relação seria ingenuidade. Onfray nos alerta a uma certa peculiaridade dessa relação: a justificativa através do respaldo à tradição. Assim escreve Onfray:

Nesse universo tão implacável quanto os outros - o sábio nunca se separa de sua adaga e de seus venenos! -, falsamente policiado, mas verdadeiramente brutal e selvagem, quem legitima o filósofo? Os estudos universitários? O concurso de ingresso ao magistério de nível médio? O doutorado? O ensino da disciplina? [...] Um Michel-Eduard Leclerc, por exemplo, aluno do seu amigo Michel Serres, diplomado pela Sorbonne, parece dificilmente merecer esse epíteto (ONFRAY, 2011, p. 1). 
Seguindo o raciocínio expresso pelo autor, a tradição sustentada pela academia seria aquela que legitimaria um trabalho desenvolvido por qualquer indivíduo enquanto filosófico ou não-filosófico. Exemplificando, podemos imaginar um trabalho acadêmico que pretenda abordar a questão da felicidade e use como referência para tal o pensamento de Aristóteles e outro que, com a mesma pretensão use como referencial a filosofia de Pródico $^{6}$. Nesse caso, como o primeiro viria a respaldar a tradição sustentada pela academia contemporânea - visto que o autor usado como referencia respalda o modus pelo qual a filosofia contemporânea se encontra fundada -, o indivíduo responsável pela pesquisa teria, ao menos teoricamente, uma maior probabilidade de angariar o título de filósofo, já que sua pesquisa, previamente, sustentaria um caráter, dito filosófico, ancorado em sua tradição. Em contrapartida, o segundo trabalho, na perspectiva de Onfray, teria problemas já em sua intenção, visto o fato de Pródico ser um autor por deveras marginal e por suas reflexões não condizerem com aquilo entendido e defendido pela academia enquanto filosofia de fato.

Com relação a história do conhecimento humano, Onfray nos instiga a pensar que o fato de estar em afinidade com a tradição traria aqueles que se encontram em uma posição politicamente privilegiada um indiscutível status em contraposição aos demais contemporâneos de sua época, visto o fato de ter o seu discurso/posição/ação respaldado por uma tradição previamente respeitada e dotada de uma posição de destaque dentre muitos. Aquilo que outrora alguma hipotética grande figura, digna de respeito devido a uma pseudo genialidade intrínseca erigiu e passou a ser aceito e difundido enquanto verdade a tempos atrás coroaria, segundo Onfray com a mesma glória o discurso/posição/ação daquele que o respaldasse tempos depois, justificando assim na perspectiva do autor a hegemonia de um discurso dominante.

Quando refletimos acerca da filosofia, como é pretendido pelo autor, temos um claro processo possível de ser observado até os dias atuais: respaldar a autoridade alocada na tradição atribui autoridade ao discurso contemporâneo. Justificando assim a constante repetição de autores/sistemas/escolas usadas como referencial para as pesquisas em filosofia.

Dessa maneira, Onfray desconstrói a ideia de genialidade intrínseca atribuída a certas figuras históricas que compões a grande história da filosofia até a

\footnotetext{
${ }^{6}$ Pródico de Ceos (465-395 a.c), filósofo grego do primeiro período do movimento sofista, pouco conhecido segundo Onfray devido sua pouca relação com a filosofia de Platão. Ainda que este tenha uma grande proximidade com o pensamento de Sócrates, Pródico acabou abandonado ao esquecimento, sendo hoje por poucos lembrado.
}

\begin{tabular}{|l|l|l|l|l|}
\hline Revista Dialectus & Ano 1 & n. 2 & Janeiro-Junho 2013 & p. 165-179 \\
\hline
\end{tabular}


contemporaneidade e institui a participação dos mesmos no corpus de sua história devido a um processo orientado pelo princípio do poder que visaria a instauração de um modus pelo qual a filosofia passaria a ser legitimada. Tal ânsia por poder estaria fundado em um conflito de caráter fundamentalmente político-segregário, onde a ascensão e a instauração de um modus filosófico ancorado na lógica e no imperativo da razão passaria a ser a negação de todo um pensamento marginal que partiria, por sua vez, de princípios alternativos, mesmo que voltados para o mesmo fim. Enfim, aqueles que respaldariam a tradição passariam a ter o epíteto de filósofos de fato, em contrapartida, os pensadores marginais, passariam a ser reconhecidos apenas como seus algozes, recebendo o título, muitas vezes com um caráter pejorativo de teóricos, eruditos ou até mesmo de quasefilósofos.

Assim temos enquanto síntese uma resposta à instigante concepção filosófica concebida por Onfray: a filosofia é resultante de um grande jogo de poder que através da organização de alguns pensadores e da desestruturação de meios alternativos de se pensar a humanidade e o mundo em sua complexidade, teve como resultante a instauração de um modus que acabaria por instituir a verdade filosófica, sendo este o critério usado para segregar o filosófico do não-filosófico. O mesmo viria a promover o desenvolvimento de um saber que, ao pretender ser filosófico, acabaria por ter de respaldar a tradição que o precedera, impedindo e ao mesmo tempo sepultando o pensamento marginal e/ou alternativo frente ao poder da instituição acadêmica, única dotada da faculdade de outorgar o título de filósofos de fato.

\section{A História dos Vencedores}

Exposto a perspectiva de Michel Onfray acerca de sua concepção de filosofia e entendido o quanto a tradição e o respaldo histórico corroboram para a hegemonia do saber filosófico na contemporaneidade, nos é possível avançar para a segunda parte do presente artigo, onde será pretendido apresentar algumas das acusações erigidas pelo autor a determinados períodos da história da humanidade onde, segundo Onfray, certas transformações vieram a contribuir para a ascensão e o sustento de um saber filosófico hegemônico, possível de ser observado de seus primórdios até os dias atuais.

Recorrendo a uma investigação materialista da história, Onfray retoma alguns determinados momentos da história da humanidade para assim apresentar uma perspectiva crítica e alternativa frente as transformações que vieram, segundo o autor,

\begin{tabular}{|l|l|l|l|l|} 
Revista Dialectus & Ano 1 & n. 2 & Janeiro-Junho 2013 & p. 165-179 \\
\hline
\end{tabular}


promover o desenvolvimento hegemônico daquilo que concebemos hoje enquanto filosofia. Com a finalidade de desestruturar as fundações as quais a filosofia ancora sua prática - a saber, a academia e a tradição por esta sustentada -, o autor nos instiga a observar a história da filosofia de maneira cética, de certa modo, com fins de defender sua tese, nos orientando a perceber o jogo político que fizera com que uma única maneira de se pensar a filosofia ascendesse e outras, por conseqüência desse mesmo processo, viessem a perecer.

O primeiro movimento o qual o autor acusa ser o movimento de ascensão dessa dita hegemonia do saber filosófico se refere a antiguidade, em específico, seu primeiro articulador: Platão (427-347 a.c). Assim escreve o autor:

Vamos ficar com exemplos da Antiguidade: por que manter a ficção de um
corpus fechado de pré-socráticos, apesar da irredutibilidade da centena de
pessoas inscritas nesse exército caótico de que alguns às vezes ultrapassam a
periodização que lhe é atribuída? Por que razão Platão nunca cita Demócrito
em sua obra completa, ao passo que todo seu trabalho pode ser lido como uma
máquina de guerra lançada contra o materialismo? Como explicar que nunca
se explore a informação dada por Diógenes Laércio que relata o desejo
enfurecido do autor do Fédon de destruir num auto-de-fé todas as obras...
justamente de Demócrito? Por que dar crédito à figura de um Sócrates
platonizado quando uma imagem mais próxima de Diógenes de Sinope ou de
Aristipo de Cirene permite abordar a obra do sátiro ultrapassando o simples
apoio à idéia platônica? Como compreender o silêncio que se observa a
respeito de Aristipo e do pensamento cirenaico em todos os diálogos de Platão?
O pensador de Cirene aparece nele apenas uma vez, e com malevolência:
Platão sublinha a indignidade de sua ausência no dia da morte de Sócrates...
(ONFRAY, 2008a, p. 14).

As palavras de Onfray nos instiga a abordar o período antigo da história da humanidade, em especial a Grécia de Platão, como um verdadeiro campo de batalhas de onde emergiria a fundamentação do modus pelo qual a filosofia passaria a ser escrita/trabalhada em todo o discorrer de sua história até a contemporaneidade. Enquanto filósofo dotado de um modus próprio de entender o mundo e a humanidade em sua complexidade, Platão apenas configuraria uma das muitas maneiras de se pensar as inúmeras questões que até então mantinham a humanidade em um suposto desconforto existencial. $\mathrm{O}$ fato de Platão ter claramente definido o que constitui a filosofia, o filosofar e por consequência a não-filosofia (vide suas obras como $O$ Banquete $^{7}$ e os diálogos de Teeteto, em especial $O$ Sofista ${ }^{8}$, nos apresenta apenas a ação

\footnotetext{
${ }^{7}$ Tendo como destaque o discurso de Sócrates, onde este, ao conversar com Diotima entende que, em resumo, ao ser humano, caberia apenas amar o saber e nunca possuí-lo. (Platão, 2005).

${ }^{8}$ Ressaltando-se nessa obra a clara definição daquilo que constitui a ação de um não-filósofo enquanto descrição da prática sofista. Em resumo, o sofista representaria, segundo a perspectiva de Platão, um imitador da verdadeira ideia de sabedoria, visto o uso que este faria da lógica discursiva para defender sua
}

\begin{tabular}{|l|l|l|l|l|} 
Revista Dialectus & Ano 1 & n. 2 & Janeiro-Junho 2013 & p. 165-179 \\
\hline
\end{tabular}


de um determinado indivíduo que pretendera definir a verdade filosófica como outros igualmente o fizeram nesse mesmo período. Mas o que Onfray aponta em sua obra é que o movimento histórico é um movimento de poder que respalda e ressalta aqueles que serão lembrados enquanto vencedores pelas gerações seguintes, assim, surge a questão: Por que Platão?

Segundo a perspectiva do autor, Platão se tornou uma figura célebre, aceita e difundida pelas gerações seguintes devido a um conjunto de fatores que o destacaram dentre os demais pensadores de sua época: sua posição política de literário, detentor de certo poder aquisitivo, exímio produtor de obras filosóficas que, em detrimento a seus algozes, tinham suas cópias distribuídas a larga escala e por fim, não menos importante, devido o fato deste ter sido regente de uma instituição - a academia - que por sua vez hierarquizou o saber filosófico. Nesse sentido, a hierarquia estabelecida pela academia de Platão traria um sentido evolutivo ao pensamento filosófico por ela trabalhado. Muito similar ao procedimento adotado pela academia contemporânea e outras inúmeras instituições de ensino - a saber, o ensino escolar -, a academia de Platão instaurou um sistema de escala de graus onde para se ter acesso a um conhecimento avançado acerca da filosofia, o estudante membro desta instituição teria de cumprir certos requisitos exigidos para tal, não muito diferente dos anos escolares e suas respectivas disciplinas que constituem seu corpus. A hierarquia defendida pela academia traria, segundo Onfray, um grau de seriedade aos estudos filosóficos e a concepção de que a filosofia constitui um saber de acesso restrito, isto é, reservado aqueles poucos que viessem a cumprir os requisitos necessários para avançar em seus estudos.

Essa perspectiva essencialmente política acerca da ascensão da filosofia de Platão opõe-se a visão clássica defendida e difundida por inúmeros historiadores da filosofia que atribui ao filósofo um valor intrínseco a suas ideias. O que levaria o mesmo ao destaque e outros ao esquecimento seria sua posição de poder frente aos seus pseudo-algozes filosóficos - poder esse de caráter sócio-político e econômico. Partindo de tal perspectiva, Onfray nos instiga a abordar Platão como um personagem que alcançara tamanho grau de prestigio em sua época, pouco devido a sua posição filosófica, mas sim, devido ao status por este sustentado. Dessa maneira, a filosofia de Platão passaria a representar o verdadeiro modus pelo qual seria possível se alcançar a verdade frente aos outros muitos modus de se pensar/agir de maneira igualmente 
filosófica. Assim Platão, segundo a perspectiva de Onfray, acabaria por instituir aquilo que viria a ser a verdadeira filosofia, cabendo aos futuros pensadores que almejassem para si tal alcunha, adotar o modus filosófico instituído por Platão como o verdadeiro, e por que não afirmar, único modelo possível de sustentar o título de filosofia de fato.

Com o período medieval e a ascensão do cristianismo enquanto religião em larga expansão, o respaldo a filosofia que outrora abordava questões como prudência, ética, justiça, desapego ao empírico/material e que ao mesmo tempo buscava orientar seus leitores ao cultivo de um saber altamente valorizado e considerado essencial para um melhor viver em sociedade, não poderia ser negligenciado. Já que a filosofia de Platão se encontrava como a verdadeira essência do saber filosófico instituído pelos antepassados pré-cristãos - segundo Onfray, devido ao status político ostentado por Platão e sua instituição -, a filosofia pretendida pelos pensadores do período cristão precisaria respaldar aquele que definira a verdade acerca da filosofia e aliar suas crenças ao modus filosófico instituído, claro, caso pretendesse dividir o mesmo status filosófico sustentado por Platão e sua academia. Desse modo, os textos que viessem a abordar tal modus de se conceber a filosofia, passariam a ser claramente privilegiados na prática do palimpsesto ${ }^{9}$ e igualmente passariam a compor o arcabouço teórico desse grande período da história da humanidade. Escreve Onfray:

\footnotetext{
Quando se passa do papiro em rolo para o códice em peles de animais, essa revolução causa a perda do que é descartado na recopiagem. Muitas obras simplesmente desaparecem.

Nos recantos, o que foi poupado por saques, terremotos, incêndios, pilhagens, vandalismos humanos e desgastes do tempo é abandonado. Nem sempre grande coisa... As peles de animais nas quais se escrevem os textos às vezes são raspadas para servir a outros autores - a República de Cícero, por exemplo, desaparece sob o Comentário dos Salmos de Santo Agostinho...-, pois às vezes são escassas: o mais antigo manuscrito da Vulgata latina exigiu mil quinhentas e cinquenta peles de bezerro... Às vezes apaga-se o traçado antigo em favor daquilo que está na moda (ONFRAY, 2008b, p.11).
}

Assim, teríamos o segundo movimento histórico que corroboraria para com a tese defendida por Onfray de que a história da filosofia corresponde a um grande jogo de poder articulado por um processo de respaldo àquele que outrora instituiu aquilo que viria a ser a verdadeira filosofia - a saber, Platão -, o que instituiria igualmente um critério de demarcação entre o filosófico e o não-filosófico. Esse segundo movimento seria o do respaldo à tradição.

\footnotetext{
${ }^{9}$ Também conhecido como recopiagem, o palimpsesto tem origem na palavra grega $\pi \alpha \lambda i ́ \mu \psi \eta \sigma \tau o \zeta$, ou palimpsestos, que em sua etimologia significa basicamente "riscar novamente".
}

\begin{tabular}{|l|l|l|l|l|}
\hline Revista Dialectus & Ano 1 & n. 2 & Janeiro-Junho 2013 & p. 165-179 \\
\hline
\end{tabular}


O movimento de respaldo a tradição garante aquele que respalda uma certa estabilidade, e atribui ao discurso erigido um status por deveras invejável de seriedade e respeitabilidade, vide o fato deste promover um diálogo com aqueles que outrora angariaram uma posição de prestigio, lembrado enquanto parte história. Para Onfray, dialogar com a tradição que passou a ser reverenciada e coroada como parte da história de uma área do conhecimento, seja ela qual for, atribui àquele que respalda uma espécie de titulação que o destaca dentre os demais membros de sua estirpe. Enfim, ao tratarmos da filosofia, em específico: referenciar o passado é o mesmo que reverenciá-lo, assim o sustentando em seu trono para as próximas gerações.

Seguindo essa mesma linha de raciocínio, aqueles que outrora foram abandonados pela tradição, incluindo aqueles depreciados pela mesma, caso sejam referenciados, acarretaria aquele que os referenciar, todo fardo do status a eles atribuídos pela filosofia acadêmica instituída e carregados por muitos até a contemporaneidade: os famigerados e pouco almejados títulos de marginais, boêmios, revoltados, rebeldes e, como já fora mencionado, o título de pseudo-filósofos.

Assim, com a ascensão do cristianismo, a escolha entre aquilo que seria preservado em suas bibliotecas e o que seria abandonado à prática do palimpsesto nos parece clara. Com a finalidade de estabelecer sua filosofia em toda a Europa medieval, Platão e seus discípulos passariam a compor o corpus de todo saber cristão, desse modo, através desse movimento, outorgando a filosofia cristã o mesmo status de seu interlocutor maior outrora reverenciado pela história.

Enfim, para Onfray, o processo iniciado na Grécia antiga teria se mantido vigente até a contemporaneidade através da prática das instituições acadêmicas que corroboram para com a manutenção dessa mesma lógica: selecionar o passado para que esse respalde a ação do presente, algo que, por consequência, viria a determinar o futuro.

\section{Conclusão}

Mesmo que a obra de Michel Onfray possa ser um tanto indigesta para alguns, sendo motivo de rechaço para muitos, ela nos desperta a pensar acerca da história da filosofia a partir de um ponto de vista não hegemônico, permitindo um rompimento com aquilo que outrora fomos acostumados a pensar enquanto frutos de uma formação

\begin{tabular}{|l|l|l|l|l|} 
Revista Dialectus & Ano 1 & n. 2 & Janeiro-Junho 2013 & p. 165-179 \\
\hline
\end{tabular}


filosófica que teima em repetir as mesmas ditas verdades acerca dessa narrativa, estranhamente linear, do desenvolvimento do conhecimento humano.

Ainda que a filosofia de Onfray soe aos ouvidos da tradição como apenas mais um discurso oriundo de um rebelde ${ }^{10}$ o qual não incorporou o espírito ostentado pela filosofia ocidental, sua pretensão em desvelar a mecânica pela qual toda a história da filosofia veio a ser desenvolvida até a contemporaneidade, acreditamos, deve merecer alguma atenção.

Desse modo, o presente artigo pretendeu apresentar, de maneira sucinta a filosofia da história de Michel Onfray e sua concepção de como o modus pelo qual a grande filosofia fora instituída enquanto movimento político, acabaria por promover o surgimento de um critério de demarcação entre o filosófico e o não-filosófico. Algo que, por sua vez, passaria a ser determinante do filosofar até os dias atuais, devido a prática do referenciar aqueles que outrora se encontrariam em uma posição privilegiada na história. Sua consequência? O sustento de uma hegemonia filosófica e a garantia, àquele que referenciar e, teoricamente, reverenciar a tradição, da aquisição do título de filósofos de fato.

Acreditando na merecida atenção aos estudos da filosofia da história e da teoria desenvolvida por Onfray enquanto possibilidade viável para uma concepção da história da filosofia, concluímos o presente artigo com a esperança de novos estudos a serem desenvolvidos em torno dessa mesma temática.

\section{Referências Bibliográficas}

FRANCA, Leonel. Noções de história da filosofia. 23ed. Rio de Janeiro: Agir, 1987.

ONFRAY, Michel. Contra-história da filosofia - 1: as sabedorias antigas. Tradução: Monica Stahel. 1ed. São Paulo: Martins Fontes, 2008a.

Contra-história da filosofia - 2: o cristianismo hedonista. Tradução: Monica Stahel. 1ed. São Paulo: Martins Fontes, 2008 b.

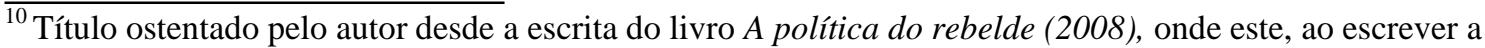
primeira parte de sua obra, relata sua não adaptação à dinâmica da vida contemporânea, focando no processo de integração promovida pelo sistema político-econômico moderno o qual é acusado de orientar a vida de inúmeros indivíduos, segundo Onfray, a um largo processo de desumanização.
}

\begin{tabular}{|l|l|l|l|l|}
\hline Revista Dialectus & Ano 1 & n. 2 & Janeiro-Junho 2013 & p. 165-179 \\
\hline
\end{tabular}


Contra-história da filosofia - 3: libertinos barrocos. Tradução: Eduardo Brandão. 1ed. São Paulo: Martins Fontes, 2009.

2001.

. A política do rebelde. Tradução: Mauro Pinheiro. Rio de Janeiro: Rocco,

. Misérias (e grandezas) da filosofia. Tradução: Iraci Poleti. Disponível em:

http://diplo.uol.com.br/imprima1003. Acessado em: 10/01/2011.

PLATÃO. O Banquete. Tradução de Heloisa da Graça Burati. São Paulo: Rideel, 2005.

PLATÃO. Teeteto. Tradução de Carlos Alberto Nunes. Disponível em: http://www.cfh.ufsc.br/ wfil/teeteto.pdf. Acessado em: 25/02/2013. 